\title{
Novel PAM Complex as Rheology Modifier and Fluid Loss Controller for Montmorillonite Fluid
}

\author{
Rakshith R. Shettigar, Nirendra M. Misra, and Khushbu Patel
}

\begin{abstract}
Fluid loss controller improves the fluid retention capacity of drilling fluid during the oil and gas drilling process. Cetyltrimethylammoniumbromide modified polyacrylamide acts as a rheology modifier and fluid loss controller at very low concentration of $0.2 \%(w / v)$ in water-based mud. The performance of polyacrylamide complex in the Na-montmorillonite fluid was analysed by using it in powder and gel form. The dispersed drilling fluid was formulated using pre-hydrated montmorillonite chrome free lignosulphonate and $\mathrm{Na}_{2} \mathrm{SO}_{3}$. Experimental results show that polyacrylamide complex provides Enhanced fluid loss control and excellent shear thinning rheology property to the fluid. Performance efficiency of polyacrylamide complex is studied in non-weighted and weighted fluid system. The bridging efficiency of polyacrylamide complex in the fluid was confirmed by analysing fluid cake in scanning electron microscope and energy dispersive $\mathrm{X}$-ray spectroscopy.
\end{abstract}

Index Terms-Fluid loss control, gel strength, rheology modifier, shear thinning.

\section{INTRODUCTION}

Customised drilling fluids (mud) play a major role in exploration and production of Oil and gas. Drilling fluids are also called as Non-Newtonian fluids as they possess thixotropic shear- thinning property with a yield stress [1]. Key functions of mud are carrying drilling cuttings to the surface, lubricating drilling tools, maintaining the stability of wellbores, and preventing the influx of the formation fluids [2]-[5].

Rheology modifier performs a crucial role in the drilling fluid, in suspending weighting agents, cutting transport, hole cleaning through low shear rate viscosity, lubrication etc. The rheological property is due to the hydrophobic interaction of surfactant with polymer chain [6], [7]. High gel strength and low-shear-rate viscosity due to rheology modifier are the key parameters to reduce the formation damage. A few vegetable-based gums gave desirable rheology even at high temperatures [8]. Montmorillonite stabilised by polymer showed excellent fluid retention capacity and stable rheology even at high temperature [9].

Polyacrylamide (PAM) gels possess water retention capacity and prevent the intrusion of water through the formation, blocking the influx flow from water producing zones [10]-[12]. Inhibitive water-based mud is suitable fluid

Manuscript received April 5, 2017; revised July 20,2017.

The authors are with the Department of Science, School of Technology, Pandit Deendayal Petroleum University, Gandhinagar-382007, Gujarat, India (e-mail: rakshith.sphd14@sot.pdpu.ac.in). for preventing the swelling of hydrating clays. Inhibitive fluids consist of potassium chloride (KCl), partially hydrolyzed polyacrylamide (PHPA) and PAM based complexes which are responsible for the inhibitive property of the mud [13]. The macroscopic property of the polymer-surfactant complex depends on the environment of the system and the type of polyelectrolyte present on the system. The complex formed has the interaction between the alkyl chain of surfactant, polymer and also the electrostatic interaction of charged components present in the system [14]-[16]. Such complexes have also exhibited shear-thinning rheology.

Our present work involves performance analysis PAM complex in terms of a rheology modifier and fluid loss controlling additive for montmorillonite-based drilling fluid.

\section{MATERIALS AND METHODS}

\section{A. Materials}

Chrome free lignosulphonate, barite, montmorillonite, and $\mathrm{KCl}$ are drilling grade additives obtained from Gumpro Drilling Fluids. Defoamer was procured from Tiny chem. Anionic PAM (Mol. Wt. 25-30 MDa) was procured from Shandong Polymer Bio-chemicals Co. Ltd. Cetyltrimethyl ammonium bromide (CTAB), 98\%, and sodium sulphite $\left(\mathrm{Na}_{2} \mathrm{SO}_{3}\right)$ were obtained from Sigma-Aldrich.

\section{B. Preparation of PAM Complex Powder}

PAM complex was prepared by green chemistry technique. Prepared complex powder was dried at $105^{\circ} \mathrm{C}$ in an air oven and stored under moisture-free condition.

\section{Preparation of PAM Complex $\mathrm{Gel}$}

PAM complex solution was prepared by adding PAM complex powder as per mud dosage into $100 \mathrm{ml}$ of $10 \% \mathrm{KCl}$ solution. The solution is stirred at 350 400 rpm for $30 \mathrm{~min}$. Prepared complex gel is added as a pill to base mud and the final volume is adjusted to 1.0 lab barrel $(350 \mathrm{ml})$.

\section{Base Mud Preparation}

A non-dispersed conventional mud was prepared by dispersing $100 \mathrm{~g}$ montmorillonite in $1000 \mathrm{cc}$ technical water. For proper dispersion of montmorillonite $0.2 \mathrm{~g} / \mathrm{cc}$ soda ash was added. The $\mathrm{pH}$ of the sample maintained as 9.0. The montmorillonite gel was kept for 24 hours for hydration. Rheology was measured by Fann VG Meter at $600 \mathrm{rpm}$. Apparent viscosity was reduced to $10 \mathrm{cp}$ by diluting the suspension by on with technical water.

\section{E. Preparation of the Dispersed Inhibitive Drilling Fluid}

Dispersed inhibitive mud was prepared by adding the 
substances, shown in Table I, to the base mud along with PAM complexes. PH of mud maintained at 9.0.

TABLE I: MUD ADDITIVES AND THEIR FUNCTIONS

\begin{tabular}{cccc}
\hline S.No & Additive & Function & $\begin{array}{c}\text { Concentration } \\
(\mathrm{w} / \mathrm{v}) \%\end{array}$ \\
\hline 1 & $\begin{array}{c}\text { Chrome free } \\
\text { lignosulphonate }\end{array}$ & $\begin{array}{c}\text { Dispersant } \\
\mathrm{Na}_{2} \mathrm{SO}_{3}\end{array}$ & $\begin{array}{c}\text { Oxygen } \\
\text { Scavenger } \\
\text { Foam }\end{array}$ \\
3 & Defoamer & $\begin{array}{c}\text { controller } \\
\text { Weighting } \\
\text { agent }\end{array}$ & 0.2854 \\
4 & Barite & 10 & 0.1 \\
\hline
\end{tabular}

\section{F. Fourier Transform Infrared Spectroscopy (FT-IR) Measurements}

FTIR spectra of PAM complex were recorded on PerkinElmer Spectrum 2 (Software: Version 10.4.2). 2 mg PAM Complex and $200 \mathrm{mg} \mathrm{KBr}$ were fully blended. A hydraulic press was used to prepare $\mathrm{KBr}$ pellet, each time exerting $20 \mathrm{MPa}$ pressure.

\section{G. Scanning Electron Microscopy (SEM) and Energy Dispersive X-Ray Spectroscopy (EDX)}

Mud cakes were analysed using ZEISS, ULTRATM55 SEM. Mud cake sample was dispersed in ethanol and coated on carbon tape, dried. The sample was sputtered using gold/ palladium (Au/Pd) sputter with Leica EM, ACE-200 coater. Argon was used as an inert gas source for coating sample to a depth of $3 \mathrm{~nm}$.

\section{H. Analysing Fluid Property}

Mud rheology was measured using Fann VG meter at 600 rpm, $300 \mathrm{rpm}, 6 \mathrm{rpm}$ and $3 \mathrm{rpm}$ as per standard protocols. OFITE fluid loss apparatus was used to study the fluid loss controlling property of PAM complex. API Fluid loss test was carried out for 30 minutes under a pressure of 100 psi and temperature $25{ }^{\circ} \mathrm{C}$. Mud weight was measured using calibrated OFITE mud balance. Rheology, fluid loss, and mud weight were analysed by following standard American petroleum institute (API) test procedure [17].

\section{RESUlt AND DISCUSSION}

\section{A. FTIR Characterization of PAM Complex}

FTIR spectra confirm the formation of PAM complex by the interaction of CTAB with PAM. On comparing PAM complex spectra with PAM it is observed that few peaks disappeared at $3341.4 \mathrm{~cm}^{-1}, 3185.16 \mathrm{~cm}^{-1}, 1657.5 \mathrm{~cm}^{-1}$ of PAM and formation of new peaks at $1462.31 \mathrm{~cm}^{-1}, 960.26$ $\mathrm{cm}^{-1}$ confirms the structural modification. FTIR spectra and peak details of PAM complex are shown in Fig. 1 and Table II respectively.

\section{B. Solubility of PAM and PAM Complex}

The solubility of PAM and PAM complex were separately examined in de-ionized water, $5 \%$ salt solution of $\mathrm{KCl}, \mathrm{NaCl}$ and $10 \%$ salt solution of $\mathrm{KCl}, \mathrm{NaCl}$. Results are shown in Table III.

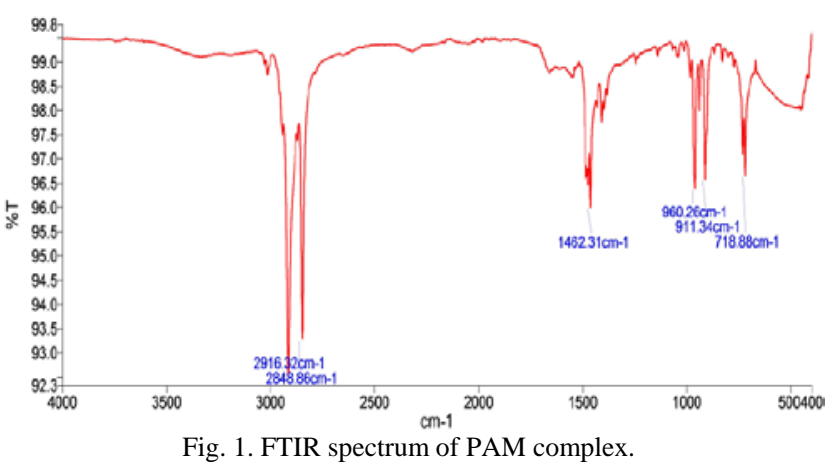

TABLE II: PEAK FREQUENCY AND FunCtionAl GROUPS OF PAM

\begin{tabular}{cccccc}
\multicolumn{6}{c}{ COMPLEX } \\
\hline Peak & $\begin{array}{c}\text { Frequency } \\
\left(\mathrm{cm}^{-1}\right)\end{array}$ & $\begin{array}{c}\text { Functional } \\
\text { group }\end{array}$ & Peak & $\begin{array}{c}\text { Frequency } \\
\left(\mathrm{cm}^{-1}\right)\end{array}$ & $\begin{array}{c}\text { Functional } \\
\text { group }\end{array}$ \\
\hline 1 & 2916.32 & $\begin{array}{c}\text { C-H } \\
\text { stretching } \\
\text { C-H } \\
\text { stretching }\end{array}$ & 3 & 1462.31 & $\begin{array}{c}\text { C-N } \\
\text { stretching } \\
\text { C-C } \\
\text { bending }\end{array}$ \\
\hline
\end{tabular}

TABLE III: SOLUBILITY OF PAM AND PAM COMPLEX

\begin{tabular}{cccc}
\hline S. No & Solvent & PAM & PAM Complex \\
\hline 1 & De-ionized Water & Soluble & Insoluble \\
2 & $5 \% \mathrm{NaCl}$ solution & Soluble & Partially soluble \\
3 & $5 \% \mathrm{KCl}$ solution & Soluble & Partially soluble \\
4 & $10 \% \mathrm{NaCl}$ solution & Soluble & Soluble \\
5 & $10 \% \mathrm{KCl}$ solution & Soluble & Soluble \\
\hline
\end{tabular}

\section{Performance Analysis of PAM Complex Powder in} Montmorillonite Mud

Prepared PAM complex powder was treated with base mud at different concentration varying from $0.2 \%(\mathrm{w} / \mathrm{v})$ to $0.5 \%(\mathrm{w} / \mathrm{v})$ to formulate the non-weighted mud (NWM). Final $\mathrm{pH}$ of the mud was maintained at 9.0.

On increasing the concentration of the additive sharp increase in the yield point (YP) of the mud was observed. Plastic viscosity (PV) was found to be stable for all concentration. Higher YP/PV ratio showed that mud has excellent cutting transport capacity. Low shear rate viscosity of the mud were determined by measuring $6 \mathrm{rpm}$ reading. Mud was found to be stable and $>6$. It signified that the possibility of the settling of cutting is negligible. $\mathrm{Gel}_{0}$ and $\mathrm{Gel}_{10}$ gel strength confirm the formation of a progressive gel. Rheology properties are shown in Table IV.

Above prepared mud is treated with $10 \%(\mathrm{w} / \mathrm{v})$ barite to determine solid tolerance and high-density profile of the mud. Results showed that the rheology remained unaltered in presence of the solid showing that the mud can be used for high-density mud systems. Rheology properties of weighted mud (WM) are shown in Table V.

Fluid loss analysis of both non-weighted and weighted mud was carried out using API fluid loss apparatus. It is observed that the non-weighted mud showed an excellent fluid retention capacity with an increase in concentration. At an optimum concentration, fluid loss was reduced to 8.8cc in absence of solid. Experimental results showed that the prepared additive can also be used for solid free mud. In weighted mud system, fluid retention capacity was further enhanced and controlled to 8cc. Mud cake formed was very thin, impervious and has got a thickness of less than $1 \mathrm{~mm}$. Fluid loss controlling property of PAM complex powder was 
by pore plugging mechanism of PAM complex on hydrated montmorillonite clay sheets. Fluid loss results are shown in Fig. 2.

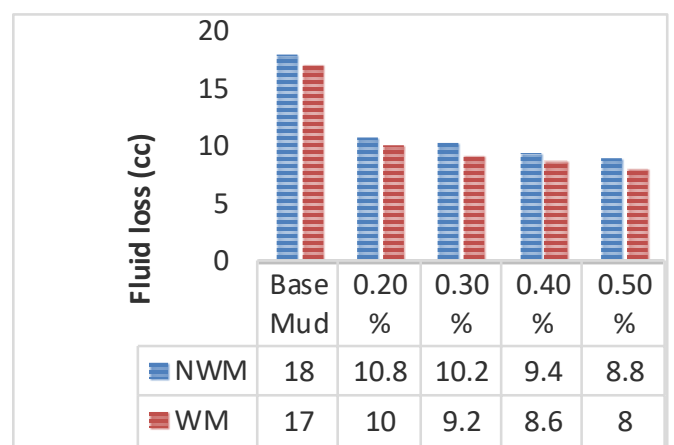

Fig. 2. Fluid loss controlling property of PAM complex powder.

\section{Performance Analysis of PAM Complex Powder in Montmorillonite Mud}

Prepared PAM complex gel is treated with base mud at a different concentration varying from $0.4 \%(\mathrm{w} / \mathrm{v})$ to $1.0 \%$ $(\mathrm{w} / \mathrm{v})$ to formulate the non-weighted inhibitive mud (NWM). Final $\mathrm{pH}$ of the mud is maintained at $\mathrm{pH}=9.0$. On increasing the concentration of the additive it is observed that there was a drastic increase in the yield point of the mud. Plastic viscosity was unaltered due to the low solids present in the mud. Compare to PAM complex powder treated mud PV and YP was slightly less and mud was highly dispersed. Higher $\mathrm{YP} / \mathrm{PV}$ ratio achieved from the formulation enhances the cutting transport capacity of the fluid. PAM complex showed a progressive gel formation in $\mathrm{Gel}_{0}$ and $\mathrm{Gel}_{10}$. Formation of low gel strength confirms that mud was more uniformly dispersed. The low shear rate viscosity recorded from measuring $6 \mathrm{rpm}$ reading, was found to be $>6$ and which indicates the better cutting carrying capacity of the fluid. Rheology properties and mud weight data are as shown in Table VI. Fluid losses were reduced on the addition of PAM complex gel to the base fluid. Fluid loss controlled from 18 cc to 8.8 cc in NWM. Fluid loss results are shown in Fig. 3.

Weighted mud (WM) system was formulated by adding $10 \%(\mathrm{w} / \mathrm{v})$ to the above prepared fluid. The increase in the apparent viscosity and Yield point was negligible with respect to NWM. Stable plastic viscosity and gel strength further confirms that fluid is uniformly dispersed and has got potential tolerance towards high gravity solids. Rheology properties and mud weight data are as shown in Table VII. Fluid loss controlling property was enhanced from 17 cc to $7.8 \mathrm{cc}$ in presence of fine solids showing that PAM complex gel has got excellent solid tolerance capacity.

TABLE IV: PAM COMPLEX POWDER TREATED WITH NON-WEIGHTED MUD

\begin{tabular}{|c|c|c|c|c|c|c|c|}
\hline $\begin{array}{c}\text { Concentration } \\
\%(w / v)\end{array}$ & $\begin{array}{l}A V \\
(c P)\end{array}$ & $\begin{array}{l}P V \\
(c P)\end{array}$ & $\begin{array}{c}Y P \\
\text { (Lbs/100sq.ft) }\end{array}$ & $6 \mathrm{rpm}$ & $\begin{array}{c}\mathrm{Gel}_{0} \\
\text { (Lbs/100sq.ft) }\end{array}$ & $\begin{array}{c}\text { Gel }_{10} \\
\text { (Lbs/100sq.ft) }\end{array}$ & $\begin{array}{c}\text { Mud Weight } \\
(g / c c)\end{array}$ \\
\hline Base Mud & 10 & 3 & 14 & 10 & 10 & 17 & 1.03 \\
\hline 0.2 & 23.5 & 15 & 17 & 11 & 11 & 31 & 1.03 \\
\hline 0.3 & 27.5 & 15 & 25 & 12 & 11 & 30 & 1.03 \\
\hline 0.4 & 32.5 & 15 & 35 & 12 & 12 & 30 & 1.03 \\
\hline 0.5 & 38.5 & 15 & 47 & 13 & 13 & 31 & 1.03 \\
\hline
\end{tabular}

TABLE V: PAM COMPLEX POWDER TREATED WITH WEIGHTED MUD

\begin{tabular}{|c|c|c|c|c|c|c|c|}
\hline $\begin{array}{c}\text { Concentration } \\
\%(w / v)\end{array}$ & $\begin{array}{l}A V \\
(c P)\end{array}$ & $\begin{array}{l}P V \\
(c P)\end{array}$ & $\begin{array}{c}Y P \\
(\text { Lbs/100sq.ft) }\end{array}$ & $6 \mathrm{rpm}$ & $\begin{array}{c}\mathrm{Gel}_{0} \\
\text { (Lbs/100sq.ft) }\end{array}$ & $\begin{array}{c}\text { Gel }_{10} \\
\text { (Lbs/100sq.ft) }\end{array}$ & $\begin{array}{c}\text { Mud Weight } \\
(g / c c)\end{array}$ \\
\hline Base Mud & 10 & 3 & 14 & 11 & 10 & 17 & 1.10 \\
\hline 0.2 & 24 & 15 & 18 & 11 & 11 & 30 & 1.10 \\
\hline 0.3 & 28.5 & 16 & 25 & 12 & 11 & 30 & 1.10 \\
\hline 0.4 & 33 & 16 & 34 & 12 & 12 & 30 & 1.10 \\
\hline 0.5 & 39 & 16 & 46 & 13 & 13 & 30 & 1.10 \\
\hline
\end{tabular}

TABLE VI: PAM COMPLEX SOLUTION TREATED WITH NON-WEIGHTED MUD

\begin{tabular}{|c|c|c|c|c|c|c|c|}
\hline $\begin{array}{c}\text { Concentration } \\
\%(w / v)\end{array}$ & $\begin{array}{l}A V \\
(c P)\end{array}$ & $\begin{array}{l}P V \\
(c P)\end{array}$ & $\begin{array}{c}Y P \\
(L b s / 100 s q . f t)\end{array}$ & $6 \mathrm{rpm}$ & $\begin{array}{c}\mathrm{Gel}_{0} \\
\text { (Lbs/100sq.ft) }\end{array}$ & $\begin{array}{c}\text { Gel }_{10} \\
\text { (Lbs/100sq.ft) }\end{array}$ & $\begin{array}{c}\text { Mud Weight } \\
\text { (g/cc) }\end{array}$ \\
\hline Base Mud & 10 & 3 & 14 & 10 & 10 & 17 & 1.03 \\
\hline 0.4 & 17.5 & 11 & 13 & 6 & 5 & 11 & 1.03 \\
\hline 0.6 & 22.5 & 11 & 23 & 7 & 7 & 17 & 1.03 \\
\hline 0.8 & 28 & 11 & 34 & 8 & 8 & 17 & 1.03 \\
\hline 1.0 & 32.5 & 12 & 42 & 9 & 8 & 18 & 1.03 \\
\hline
\end{tabular}




\begin{tabular}{|c|c|c|c|c|c|c|c|}
\hline $\begin{array}{c}\text { Concentration } \\
\%(w / v)\end{array}$ & $\begin{array}{l}A V \\
(c P)\end{array}$ & $\begin{array}{l}P V \\
(c P)\end{array}$ & $\begin{array}{c}Y P \\
\text { (Lbs/100sq.ft) }\end{array}$ & $6 \mathrm{rpm}$ & $\begin{array}{c}\mathrm{Gel}_{0} \\
\text { (Lbs/100sq.ft) }\end{array}$ & $\begin{array}{c}\text { Gel }_{10} \\
\text { (Lbs/100sq.ft) }\end{array}$ & $\begin{array}{c}\text { Mud Weight } \\
(\mathrm{g} / \mathrm{cc})\end{array}$ \\
\hline Base Mud & 10 & 3 & 14 & 10 & 10 & 17 & 1.10 \\
\hline 0.4 & 18 & 12 & 12 & 6 & 5 & 11 & 1.10 \\
\hline 0.6 & 23 & 12 & 22 & 7 & 7 & 17 & 1.10 \\
\hline 0.8 & 28 & 12 & 32 & 8 & 8 & 17 & 1.10 \\
\hline 1.0 & 33 & 12 & 42 & 9 & 8 & 18 & 1.10 \\
\hline
\end{tabular}

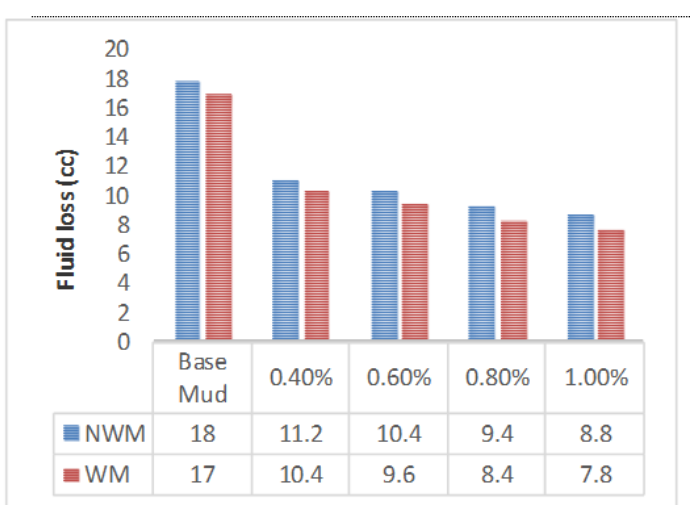

Fig. 3. Fluid loss controlling property of PAM complex solution.

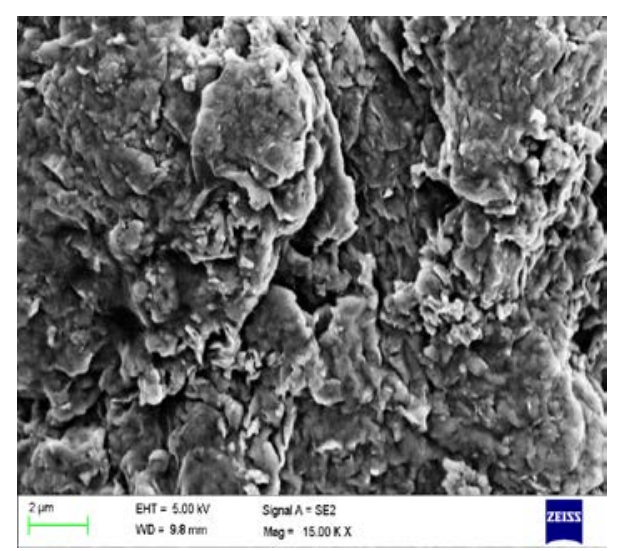

Fig. 4. SEM image of montmorillonite.

\section{A. Characterization of Mud Cake by SEM}

Mud cake was prepared from the Montmorillonite mud and fluid formulated using PAM complex gel. Prepared mud cake was dried at $105{ }^{\circ} \mathrm{C}$ in Oven. The bridging efficiency of the mud cake was investigated using SEM. SEM images of mud cake were compared with SEM image of montmorillonite to determine the bridging efficiency. From SEM images it is confirmed that PAM complex gel forms an interlayer between the clay sheets and increase the bridging efficiency of the mud cake. Increased bridging efficiency also helps in preventing the loss of the filtrate from mud under a pressurized condition. PAM complex gel was found to be more uniformly dispersed over the clay sheets. SEM images of montmorillonite and mud cake are as shown in Fig. 4 and Fig. 5.

\section{B. Characterization of Mud Cake by EDX}

Montmorillonite and mud cakes were subjected to EDX analysis. In EDX spectrum of mud cake new peaks of S, K and $\mathrm{Cl}$ are observed. Whereas for montmorillonite the peaks for $\mathrm{S}, \mathrm{K}$ and $\mathrm{Cl}$ were absent, which shows the intercalation of PAM complex in montmorillonite clay sheets. EDX images also confirm the formation of PAM complex on clay layer as shown in Fig. 6 and Fig. 7 and elemental composition is shown in Table VIII, IX.

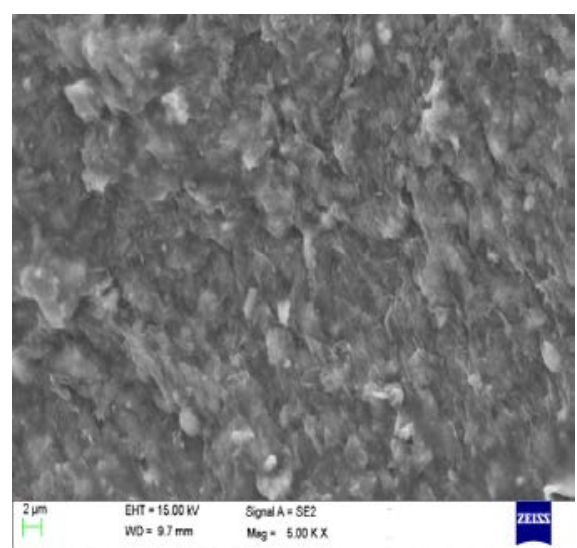

Fig. 5. SEM image of PAM complex solution treated mud cake.

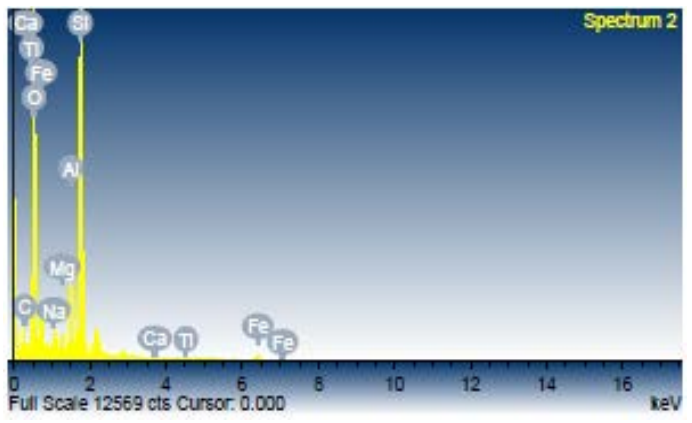

Fig. 6. Elemental spectrum of montmorillonite.

\begin{tabular}{cccc}
\multicolumn{4}{c}{ TABLE VIII: ELEMENTAL WEIGHT COMPOSITION OF MONTMORILLONITE } \\
\hline S.No & Elements & Weight $\%$ & Atomic $\%$ \\
\hline 1 & $\mathrm{C}$ & 0.03 & 9.05 \\
2 & $\mathrm{O}$ & 0.31 & 62.95 \\
3 & $\mathrm{Na}$ & 0.01 & 1.13 \\
4 & $\mathrm{Mg}$ & 0.00 & 0.66 \\
5 & $\mathrm{Al}$ & 0.02 & 2.71 \\
6 & $\mathrm{Si}$ & 0.15 & 16.94 \\
7 & $\mathrm{Ca}$ & 0.00 & 0.21 \\
8 & $\mathrm{Ti}$ & 0.00 & 0.33 \\
9 & $\mathrm{Fe}$ & 0.1 & 6.02 \\
\hline Total & & 0.64 &
\end{tabular}

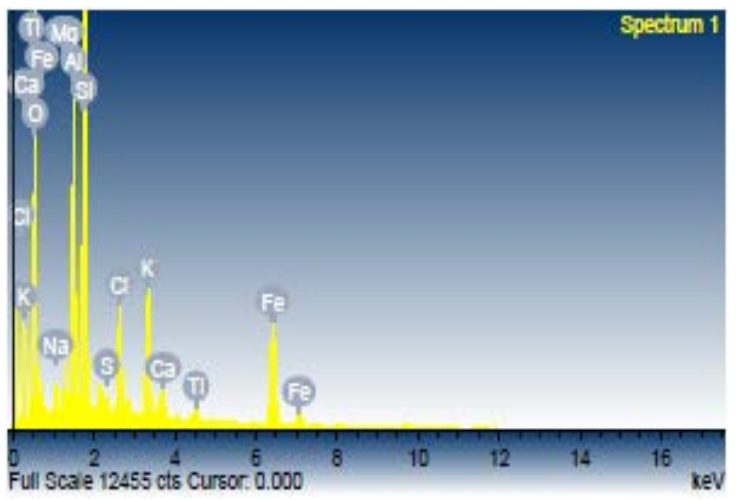

Fig. 7. Elemental spectrum of PAM complex solution treated mud cake. 
TABLE IX: ELEMENTAL WEIGHT COMPOSITION OF PAM COMPLEX TREATED MUD

\begin{tabular}{cccc}
\multicolumn{4}{c}{ TREATED MUD } \\
\hline S.No & Elements & Weight \% & Atomic \% \\
\hline 1 & $\mathrm{O}$ & 26.97 & 67.97 \\
2 & $\mathrm{Na}$ & 0.56 & 0.98 \\
3 & $\mathrm{Mg}$ & 0.57 & 0.95 \\
4 & $\mathrm{Al}$ & 3.70 & 5.53 \\
5 & $\mathrm{Si}$ & 10.62 & 15.26 \\
6 & $\mathrm{~S}$ & 0.09 & 0.12 \\
7 & $\mathrm{Cl}$ & 1.84 & 2.09 \\
8 & $\mathrm{~K}$ & 2.29 & 2.36 \\
9 & $\mathrm{Ti}$ & 0.56 & 0.57 \\
10 & $\mathrm{Ca}$ & 0.37 & 0.32 \\
11 & $\mathrm{Fe}$ & 5.35 & 3.87 \\
\hline Total & & 52.90 & \\
\hline
\end{tabular}

\section{CONCLUSION}

The Prepared PAM complex powder performance analysis carried out by using it in solid form as well as gel. On adding solid PAM complex to base mud it is observed that there is a sharp increase in the yield point with increase in additive concentration. There is a marginal variation in plastic viscosity is observed. High yield point and low plastic viscosity show that PAM complex acts effective rheology modifier with good cutting lifting capacity. On increasing the concentration of additive fluid loss controlling capacity of PAM complex also increase by reducing more than $50 \%$ fluid loss. PAM complex solution also proves to be effective viscosity enhancer as it also increases the yield point with increasing the concentration. Filtration control mechanism of complex due to pore plugging mechanism of PAM complex polymer and Montmorillonite clay sheets.

PAM complex gel shows an increase in rheology and fluid loss property at higher concentration compare to PAM complex powder. SEM, EDX images of cake formed from PAM complex gel win mud showed that the PAM layer is properly dispersed into the clay matrix of montmorillonite. PAM complex gel on treating with pre-hydrated montmorillonite formed a uniform dispersive layer between the clay sheets. These layer formed are impervious and very thin and shows an excellent fluid retention capacity.

In the solid phase, it is observed that there is an increase in rheology and control of fluid loss at lower concentration whereas in gel system, more dispersed rheology at higher concentration. PAM complex has got PAM as its major constituent which acts as a rheology modifier, shale stabilizer and alkyl chain of CTAB prevents the fluid loss in the formulation. Whereas it can be concluded that PAM complex is an effective rheology modifier and fluid loss controller in montmorillonite mud system. Inhibiting property of PAM also makes it as a highly inhibitive mud system for reactive clay formations. Clay inhibitors prevent the wellbore instability, clay sloughing and reduces the real-time drilling costs. PAM complex can be a promising versatile drilling fluid additive for the future inhibitive mud system.

\section{APPENDIX}

\section{Abbreviations}

$\begin{array}{ll}\text { YP } & =\text { Yield point } \\ \text { Gel0 } & =\text { Gel strength after } 10 \text { seconds } \\ \text { Gel10 } & =\text { Gel strength after } 10 \text { minutes } \\ \text { Lbs/ } 100 \text { sq.ft } & =\text { pounds per } 100 \text { square feet } \\ \text { cP } & =\text { centipoise } \\ \text { g/cc } & =\text { gram per cubic centimeter } \\ \text { WM } & =\text { Weighted Mud } \\ \text { NWM } & =\text { Non-weighted Mud } \\ \text { AHR } & =\text { after rot rolling } \\ \text { BHR } & =\text { before hot rolling }\end{array}$

\section{ACKNOWLEDGMENT}

The authors would like to acknowledge Petropath Fluids (India) Pvt Ltd., Gujarat, India, Gumpro drilling fluids pvt. Ltd., India and Shandong Polymer Bio-chemicals Co. Ltd., Shandong, P. R. China, for the support.

\section{REFERENCES}

[1] P. Coussot, F. Bertrand, and B. Herzhaft, "Rheological behavior of drilling muds, characterization using MRI visualization,” Oil Gas Sci. Technol. - Revue del' Institut Franc- ais duPetrole, vol. 59, pp. 23-29, 2004.

[2] R. Caenn, H. C. H. Darley, and G. R. Gray, “Composition and properties of drilling and completion fluids," Gulf Proffessional Publishing, 5th ed., 1988.

[3] P. F. Luckham and S. Rossi, "The colloidal and rheological properties of bentonite suspensions,” Adv. Colloid Interface Sci., vol. 82, no. 1-3, pp. 43-92, 1999.

[4] R. Caenn and G. V. Chillingar, "Drilling fluid: State of the art," J. Pet. Sci. Eng., vol. 14, pp. 221-230, 1996.

[5] R. R. Menezes, L. N. Marques, L. A. Campos, H. S. Ferreira, L. N. L. Santana and G. A. Neves, "Use of statistical design to study the influence of CMC on the rheological properties of bentonite dispersions for water-based drilling fluid,” Appl. Clay Sci., vol. 49, pp. 13-20, 2010.

[6] J. A. Shashkina, O. E. Philippova, Y. D. Zaroslov, A. R. Khokhlov, T. A. Pryakhina, and I. V. Blagodatskikh, "Rheology of viscoelastic solutions of cationic surfactant: effect of added associating polymer," Langmuir, vol. 21, pp. 1524-1530, 2005.

[7] D. H. Kim, J. W. Kim, S. G. Oh, J. Kim, S. H. Han, D. J. Chung, and K. D. Suh, "Effects of nonionic surfactant on the rheological property of associative polymers in complex formulations,” Polymer, vol. 48, pp. 3817-3821, 2007.

[8] F. X. Li, G. C. Jiang, Z. K. Wang, and M. R. Cui, "Drilling fluid from natural vegetable gum,” J. Pet. Sci. and Tech., vol. 32, pp. 738-744, 2014.

[9] H. E. Zilch, M. J. Otto, and D. S. Pye, "The evolution of geothermal drilling fluid in the imperial valey,” Society of Petroleum Engineers, SPE 21786 MS, 1991.

[10] R. S. Seright, "Optimizing disproportionate permeability reduction," Society of Petroleum Engineers, SPE 99443, 2006.

[11] S. Gou, T. Yin, Z. Ye, W. Jiang, C. Yang, Q. Xia, and M. J. Wu, "Water-Soluble allyl and diallyl camphor sulfonamides-based polyacrylamide copolymers for enhanced oil recovery,” Appl. Polym. Sci., vol. 132, p. 41238, 2015.

[12] R. D. Lentz, "Polyacrylamide and biopolymer effects on flocculation, aggregate stability, and water seepage in a silt loam," Geoderma, vol. 241-242, pp. 289-294, 2015.

[13] V. Mahto, P. Srikanth, and B. V. Krishna, "Development of non-damaging and inhibitive water based oil well drilling fluids," $J$. Pet. Sci. Technol., vol. 31, pp. 721-726, 2013.

[14] X. Wang, J. Wang, Y. Wang, and H. Yan, "Salt effect on the complex formation between cationic Gemini surfactant and anionic polyelectrolyte in aqueous solution," Langmuir, vol. 20, pp. 9014-9018, 2004.

[15] S. G. Starodubtsev, A. T. Dembo, and K. A. Dembo, "Effect of polymer charge density and ionic strength on the formation of complexes between sodiumarylamido-2-methyl-1-propane-sulfonateco-acrylamide gels and cetyl pyridinium chloride,” Langmuir, vol. 20, pp. 6599-6604, 2004. 
[16] X. Xin, G. Y. Xu, D. Wu, Y. M. Li, and X. R. Cao, “The effect of $\mathrm{CaCl}_{2}$ on the interaction between hydrolysed polyacrylamide and sodium stearate: rheological property study," Colloids Surf., vol. 305, pp. 138-144, 2007.

[17] American Petroleum Institute (API), "Recommended practice for field testing of water-based drilling fluids," American Petroleum Institute, 3rd ed., pp. 1-82 ANSI/API 13B-1, 2003.

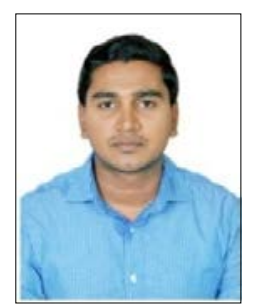

Rakshith R. Shettigar is pursuing Ph.D studies in Pandit Deendayal Petroleum University, Gandhinagar. He was born on August 20, 1990 in Mangalore, Karnataka State, India. He is a post graduate in M.Sc. chemistry from National Institute of Technology Karnataka, Surathkal, India in the year of 2013. He completed his B.Sc.in the year 2011 from Mangalore University, Mangalore, India.

His professional experience includes R\&D Engineer in Petropath Fluids (India) Pvt. Ltd., Gujarat, India and as QC/QA Chemist in Bostik India Pvt. Ltd., Bangalore, India. His research areas of interest are drilling fluids, Enhanced Oil recovery techniques and Green Chemistry.

$\mathrm{He}$ recently published/presented: "Eco-friendly extreme pressure lubricants for water based drilling fluids" by Rakshith R Shettigar, Nirendra M. Misra, Bhaskar Naik, Khushbu Patel; in an International conference on Environment, Chemistry and Biology held on November 19-21, 2015 at Auckland, New Zealand. "Preparation and characterization of silica gel from wheat straw”, by Khushbu G. Patel, Nirendra M. Misra, Rakshith R. Shettigar" in an International conference on the 2016 6th International Conference on Chemistry and Chemical Process was held in Roma, Italy during February 1-3, 2016.

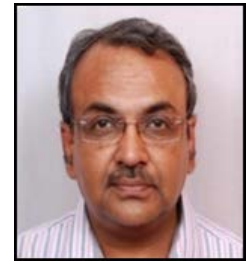

Nirendra M. Misra was born on Nov. 21, 1958. He is working at PDPU since April, 2014. He served as a faculty member at Indian School of Mines (ISM), Dhanbad for 26 years. Prior to that he had a brief stint, of 4-years, as a chemist at Oil \& Natural Gas Commision (ONGC), Ankleshwar, Gujarat. Dr. Misra is a graduate of Patna University. He did his M. Phil and Ph.D in Applied Chemistry from ISM, Dhanbad.
He has guided a number of Ph.D, M. Tech and MPhil students in different areas. His teaching includes: kinetics, statistical thermodynamics, Chemistry of lubricants, and computer applications in chemistry. Current research interest: surface properties of clays and clay minerals.

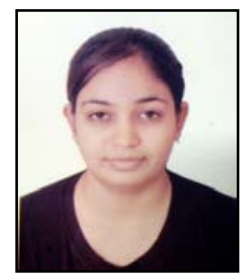

Khushbu G. Patel is pursuing Ph.D studies in Pandit Deendayal Petroleum University, Gandhinagar She was born on May 9, 1990 in Amreli, a coastal city of Gujarat State, INDIA. She is a post graduate in M.Sc. chemistry from Gujarat University, Ahmedabad, Gujarat, India in the year of 2012. She completed his B.Sc. in the year 2010 from Gujarat University, Gujarat, India.

Her professional experience includes R\&D chemist in Parshwanath Dye chemicals Pvt. Ltd., Ahmedabad, Gujarat, India. Her research areas of interests are green chemistry, catalyst and catalytic activity, organic synthesis

She recently published/presented: "Preparation and characterization of silica gel from wheat straw,” by Khushbu G. Patel, Nirendra M. Misra, Rakshith R. Shettigar in an International conference on the 2016 6th International Conference on Chemistry and Chemical Process was held in Roma, Italy during February 1-3, 2016; "Eco-friendly extreme pressure lubricants for water based drilling fluids" by rakshith R. Shettigar, Nirendra M. Misra, Bhaskar Naik, Khushbu Patel in an International conference on environment, chemistry and biology held on November 19-21, 2015 at Auckland, New Zealand. 